\title{
ПАРАДИГМАТИЧНІ ВІДНОШЕННЯ В СУЧАСНІЙ УКРАЇНСЬКІЙ ПРАВООХОРОННІЙ ТЕРМІНОЛОГІЇ
}

Аналіз термінологійних наукових праць дав можливість виявити, що украӥнська правоохоронна терміносистема (УПТ) в аспекті парадигматичних відношень ще не вивчалася. Парадигматичні зв'язки (синонімія, антонімія, паронімія) в УПТ відображають етапи становлення й розвитку правоохоронного термінологійного корпусу. Запропоновано основні напрями унормування УПТ як нової трансбормованої системи, шьо зумовить подальше формування якісно нового полічійного органу, покликаного захищати права та інтереси громадян Украйни на засадах прозорості й доступності.

Ключові слова: українська правоохоронна термінологія / терміносистема (УПТ), парадигматичні зв'язки, синонімія, антонімія, паронімія, поліційний орган.

Udovichenko L. Paradigmatic Relations in Modern Ukrainian Law Enforcement Terminology. The problem of research and, consequently, the standardization of law enforcement terminology as a system, aimed to meet the requirements of both police officers and citizens of Ukraine have arisen in connection with the modern transformation of law enforcement authorities from a militarized structure to an administrative and legal one, and their fixation on European standards.

Taking into account the number of scientific studies, concentrated on paradigmatic relations in different term systems, scholars have never focused their attention exactly on law-enforcement terminology as a system with characteristic paradigmatic relations, which is the relevance of researches in this direction.

The aim of the scientific study is to identify and explore paradigmatic relations in the system of modern Ukrainian law enforcement terminology as a strategy for its standardization.

During the analysis of terminological material, it has been identified that the paradigmatic links in Ukrainian law enforcement terminology reflect the stages of formation and development of law enforcement corpus of terms as a system. It has been noted that a characteristic feature of Ukrainian law enforcement terminology is the existence of a considerable number of terms from other humanitarian spheres, in particular jurisprudence, military science and medicine. This leads to paradigmatic relations as such, arising between words and groups of words on the basis of the similarity or opposition of their meanings (synonymy, antonymy, hyper-hyponymy, etc.). Scholars have different perceptions of the range of problems provided 
in the terminology science as it is evidenced by numerous debates that have both categorical denial and justification of stylistic conditionality.

The main directions of standardization of Ukrainian law enforcement terminology have been offered as a new transformed system, in particular the elimination of loan translations from Russian, the prevention of borrowings and the creation of a national system of terms, most accurately representing object and subject mutual relations, and current activity of law enforcement system of Ukraine. This will lead to the further formation of a qualitatively new policing authority, intended to protect the rights and interests of Ukrainian citizens on the principles of transparency and accessibility.

Keywords: Ukrainian law enforcement terminology/term system, paradigmatic relations, synonymy, antonymy, paranomy, policing authority.

\section{Вступ}

Сучасна українська правоохоронна термінологія (УПТ), що бере свій початок ще з часів формування суспільства, продовжувала становлення протягом усієї історії нашої правової держави, а також затребувала новий аспект розвитку зі створенням Національної поліції України.

Правоохоронна термінологія - це яскрава репрезентація розвитку, прогресу й створення нової формації нашої держави - дійсно демократичної, у якій захист прав та інтересів громадян забезпечується не мілітаризованим органом, а адміністративно-правовим - поліцією. Постійний розвиток суспільства, тяжіння до європейських стандартів життя зумовлюють трансформування поліції в якісно нову структуру, що покликана захищати права й інтереси громадян України.

У зв'язку із сучасною трансформацією правоохоронних органів, їхнім прагненням наблизитися до населення постала проблема дослідження правоохоронної термінології як системи з урахуванням особливостей парадигматичних відношень, що постійно перебувають у центрі уваги термінологів.

Явища синонімії, омонімії, паронімії, полісемії в різних галузевих терміносистемах стали об’єктом мовознавчого зацікавлення багатьох науковців. Зокрема, М. Є. Борисова, досліджуючи лексико-семантичні особливості англійських та українських юридичних термінів, з'ясовує особливості їх перекладу (Борисова, 2020), I. I. Ковтун приділяє увагу словотвірній і структурно-семантичній характеристиці юридичної термінології (Ковтун, 2012), Г. В. Ткач вивчає 
парадигматичні відношення в сучасній українській терміносистемі державного управління (Ткач, 2020). Низка термінологійних досліджень зорієнтована у сферу фахової мови інших галузей (Лепеха, 2000; Гуменюк, 2010; Бойко, 2020; Краснопольська, 2010; Харчук, 2017 та ін.).

Правоохоронна термінологія як мова оновленої правоохоронної системи перебуває сьогодні на стадії становлення, однак досі не була об'єктом уваги українських мовознавців, що й зумовлює актуальність цієї студії.

Мета наукової розвідки - виявити й дослідити парадигматичні відношення в системі сучасної української правоохоронної термінології як стратегію внормування УПТ; основне завдання реалізації зазначеної мети - проаналізувати особливості прояву парадигматичних відношень (синонімії, антонімії тощо) в УПТ.

\section{Методи дослідження}

У дослідженні застосовано методи аналізу та синтезу - для здійснення теоретичних узагальнень і систематизації фактичного матеріалу; метод класифікації - для групування та розмежування терміноодиниць; метод суцільної вибірки - для формування фактичної бази дослідження; описовий, у межах якого актуалізовано прийоми внутрішньої і зовнішньої інтерпретації, що спрямовано на комплексне дослідження правоохоронної термінології, і метод компонентного аналізу, який дав можливість класифікувати матеріал за парадигматичними відношеннями.

\section{Виклад основного матеріалу}

Наукові термінокомплекси часто оперують поняттями побутового мислення, тому не випадково до складу УПТ належить значний пласт загальновживаних власне українських слів, більшість із яких має загальномовне значення. Перейшовши в категорію термінів, вони втрачають свої прагматично-конвенційні властивості та набувають якісно нового й глибшого значення, окресленого термінологійними ознаками, - звужений фокус дефініювання, відсутність образності й експресії, стилістична нейтральність. Однак через свою природу такі терміноодиниці все ж таки зберігають парадигматичні зв'язки, що мають свої семантичні особливості. 
Притаманною рисою УПТ як комплексної системи $є$ наявність значної кількості термінів з інших гуманітарних сфер. У іiі активі паралельно представлена термінологія суміжних галузей знань: юриспруденції, військової справи, медицини, що провокує парадигматичні відношення, які виникають між словами й групами слів на основі спільності або протилежності їхніх значень (синонімія, антонімія, гіперо-гіпонімія тощо). Неоднозначне сприйняття цієї проблематики в термінознавстві засвідчують численні дискусії: від категоричного заперечення (Коваль, 1970: 225-226) до виправданої стилістичної обумовленості (Пілецький, 1997: 115-118).

Між загальновживаною мовою і терміносистемами наук немає суттєвих обмежень щодо синонімії та антонімії. Це свідчить про те, що межі між загальнонародною мовою й терміносистемами наук лабільні (Українська мова. Енциклопедія, 2004: 6). Але в термінології ці явища мають свою специфіку, зокрема «в загальнолітературній мові синоніми називають ту ж саму річ, але через найменування розкривають різні ознаки, відповідають різним поняттям. У термінології синоніми співвідносні з тим самим поняттям і об’єктом. Якщо в загальнолітературній мові синоніміка свідчить про лексичне багатство мови і $є$ позитивним явищем, то в термінології - це небажане явище, оскільки синоніми можуть ускладнювати спілкування й призводити до неточного розуміння юридичного тексту. Наприклад, щоб усунути неточності у вживанні, синоніми термін і строк отримали різне значення у ст. 251 Цивільного кодексу України й не можуть тепер уживатися як рівнозначні» (Мова української юриспруденції, 2020: 180-181).

Варто враховувати також і суттєву відмінність між номінаціями власне термінологійними та номенклатурними, як і між поняттями термінологія та номенклатура. Фахівці диференціюють їх за такими параметрами: (1) терміни утворюють єдину систему, номенклатура сукупність внутрішньо не пов'язаних елементів; (2) під номенклатурою варто розуміти сукупність абстрактних й умовних символів, а під термінологією - сукупність термінів, що позначають правові поняття; (3) номенклатурні слова більш номінативні, водночас як терміни дефінітивні, тому що словесно відбивають систему понять визначеної науки (див. про це: Мова української юриспруденції, 2020: 168-169).

Проаналізуймо деякі особливості вияву названих типів парадигматичних відношень в УПТ. У процесі аналізу термінологійного 
матеріалу (закони України «Про Національну поліцію» $\mathrm{i}$ «ро Дисциплінарний статут Національної поліції України», наказ Міністерства внутрішніх справ від 19.08.2017 р. № 718 «Про затвердження Правил носіння однострою поліцейських») було виявлено своєрідність парадигмальних відношень у системі правоохоронних термінів.

Термінологійна парадигма УПТ у межах синонімії відображає діахронію системи, репрезентує певні етапи розвитку, способи поповнення, що дає можливість уважати це явище корисним і позитивним щодо процесу становлення національного термінологійного корпусу. Зокрема, видається можливим окреслити такі моделі синонімії термінів УПТ:

(1) іншомовний термін - український термін, порівн.: кодекс закон, дисиипліна - внутрішній розпорядок, патрулювання - нагляд, алібі - доказ непричетності, приватний - особистий, кримінальний карниц्;

(2) іншомовний термін - калька, порівн.: доверенность (рос.) - довіреність, ценный подарок (рос.) - иінний подарунок, дисииплинарний проступок (рос.) - дисииплінарний проступок, стороны уголовного процесса (рос.) - сторони кримінального провадження, вимагательство (рос.) - вимагательство, предъявлять (рос.) - пред'являти, головной убор (рос.) - головний убір, подследственность (рос.) - підслідність, пропасть безвести (рос.) - пропасти безвісти, усиновители (рос.) - усиновителі, показания (рос.) - показання, принятие решения (рос.) - прийняття рішення;

(3) синонімія власне українських термінів, порівн.: діяння - діï, правопорушник - злочинець, законний - правомірний, протиправність - злочин, незаконний - протиправний, учасники кримінального провадження - сторони кримінального провадження, обмеження волі - позбавлення волі, підозрюваний - обвинувачений - винний, схиляння - втягнення - залучення - спонукання, близькі - родичі, захист - активна оборона, володіння - користування - розпорядження.

Синонімічні терміни УПТ поділяють на повні (абсолютні), часткові (парціальні) й відносні (релятивні). Повні (абсолютні) синоніми мають ідентичне значення, є взаємозамінними, порівн.: показання свідчення, правовий - правомірний, свавілля - беззаконня. Часткові (парціальні) синоніми - це такі терміни, що збігаються частково своїми значеннями, перебуваючи в співвідношенні частини й цілого, 
абстрактного й конкретного в різних комбінаціях, але всі вони слугують для пояснення чогось однопланового й однотипного на основі філософської аналітики та прагматики мислення (Новоставська, 2013: 72), порівн.: несення служби - службова діяльність, смерть - смерть внаслідок убивства, смерть внаслідок нещзасного випадку; матеріальний носій інформацї - аудіозапис, відеозапис, фотоплівка тощо.

Синонімія забезпечує й гіперо-гіпонімічні відношення термінів УПТ, порівн.: спеціальні засоби - зброя, кийки, наручники; формена сорочка - сорочка формена з короткими рукавами, сорочка формена трикотажна; однострій - головні убори, верхній одяг, білизна, взуття, спорядження, фурнітура; знаки розрізнення - нарукавний знак «Полічія», погони, нарукавні знаки органів та підрозділів (закладів, установ) полічіи; арешт - адміністративний арешт, домашній арешт; службова документація - рапорт, наказ, догана, подання; публічні місия - парки, сквери, вокзали, аеропорти тощо.

Термінознавці відзначають, що «антонімія більшою мірою виникає між термінами, ніж між загальновживаними одиницями» і $є$ одним із головних показників формування терміносистеми (Петрова, 2018: 89). Антонімія в термінології, як виявляється, набуває статусу найбільш зручного систематизатора, а в системі УПТ - регулятором правоохоронної та правочинної діяльності. Фахівці наголошують, що «неможливо також уявити функціонування правничої термінології без поляризації: законодавчий словник містить багато антонімів, бо закони відображають полярні інтереси - права й обов’язку» (Морщакова, 1992: 83).

Українська правоохоронна термінологія оперує сьогодні антонімічними одиницями, що називають семантично-протилежні поняття, які з погляду логіко-предметних відношень співвідносяться один з одним за різними класифікаційними ознаками.

Зокрема за структурою виокремлюємо (1) однокореневі антоніми, порівн.: дї поліцейського - бездіяльність поліцейського, небезпека - безпека, законний спосіб - незаконний спосіб; (2) різнокореневі антоніми, порівн.: тупі предмети - гострі предмети, тегке поранення - важке поранення, службові обов'язки - службові повноваження, заборона руху - дозвіл руху, метод заохочення - метод впливу.

За лексико-семантичними ознаками розрізняємо (1) антонімиконверсиви, що називають відношення, у яке вступають дві сторони 
і яке для кожної з них має протилежне значення, порівн.: заохочення - догана, приймати на службу - звільняти зі служби, дисииплінарне стягнення - грошова винагорода, наявність видимих тілесних ушкоджень - відсутність видимих тілесних ушкоджень; (2) антоніми, що виражають градуальну якісну протилежність і протилежність координаційних понять за наявності проміжного вияву ступеня певного явища: неухильне виконання - перевищення повноважень - службова бездіяльність; дисииплінарна відповідальність - дисииплінарний проступок - дисииплінарна безвідповідальність; свобода - обмеження волі - позбавлення волі; приватна власність - комунальна власність державна власність; (3) комплементарні антоніми, що відтворюють протилежність понять, характеризуються кожне своїм значенням і доповнюють одне одного до вираження всього родового поняття, порівн.: фізична особа - об'єкт права, правопорушник - правоохоронецьь тощо.

У річищі історичних подій можуть відбуватися “живі” парадигми мовних одиниць, деякі з яких можна розцінювати як своєрідні парадокси. Це стосується, зокрема, паронімічних термінів правозахисник (1) і правоохоронець (2), що в потоці подій 2014 року в Україні набули фактично антонімічних значень (Правозахисник...). У $3 \mathrm{MI}$ виникла дискусія щодо полярної зміни семантики зазначених термінів, що традиційно називали (1) особу, яка обстоює права людини й (2) співробітника правоохоронних органів. Руйнування паронімічних зв'язків спровокувало «підписання президентом резонансного закону, що обмежує права пересічних громадян на вираження протесту й захищає правоохоронні органи. А вже цими днями на вулиці Грушевського слова “правозахисник” і “правоохоронець” фактично перетворилися на антоніми...» (Правозахисник...). На сьогодні зазначені терміни регулюють діяльність правоохоронних органів влади в оновленому статусі й покликані повернути свою доброчесну семантику.

\section{Висновки}

Парадигматичні зв'язки виступають важливим чинником організованості й системності української правоохоронної термінології. Основними напрямами нормування сучасної УПТ вбачаємо усунення кальок з російської мови, запобігання запозичень і створення 
національної системи термінів, що найбільш точно репрезентують об’єктно-суб'єктні взаємовідношення, чинну діяльність правоохоронної системи України.

Як перспективу окреслюємо розроблення концепції сучасного словника української правоохоронної термінології, що забезпечить доступність, прозорість діяльності правоохоронних органів.

\section{ЛІТЕРАТУРА}

1. Коваль, А. П. (1970). Науковий стиль сучасної української літературної мови: Структура наукового тексту. Київ: Вид-во Київ. ун-ту. 2. Морщакова, Т. В. (1992). Семантические характеристики терминов уголовного закона (на материале русского, немецкого, английского языков). (Дис. ... канд. філол. наук). Москва: Воен. краснознам. ин-т. 3. Новоставська, О. (2013). Парадигматичні відношення (синонімія та антонімія) у філософській термінології творів Івана Франка. Українська мова, 2, 68-75. 4. Петрова, Т. О. (2018). Фітомеліоративна термінологія сучасної украӥнської мови та ії відображення в термінологічному словнику комбінованого типу. Харків: ТОВ «ТПГ». 5. Пивоваров, В. М., Єрахторіна, О. М., \& Лисенко, О. А. та ін. (2020). Мова украӥнської юриспрудениії. Харків: Право. 6. Пілецький, В. Деякі лінгвістичні проблеми українського термінознавства. Украӥнський правопис і наукова термінологія: проблеми норми та сучасність. Матеріали засідань Мовознавчої комісії і Комісії всесвітньої літератури НТШ у Львові 1996-1997 рр. (с. 115-118). Львів: Наук. тов-во ім. Шевченка у Львові. 7. Правозахисник vs правоохоронець? «ZN, $U A », 2,24.01 .2014$. Узято з https://zn.ua/ukr/SOCIUM/pravozahisnik-vs-pravoohoronec-.html. 8. Русанівський, В. М., Тараненко, О. О., \& Заблюк, М. П. (Ред.). Украйнська мова. Енииклопедія. (2004). Київ: Укр. енцикл. ім. М. П. Бажана.

\section{REFERENCES}

1. Koval, A. P. (1970) Naukovyi styl suchasnoi ukrainskoi literaturnoi movy: Struktura naukovoho tekstu [Scientific style of modern Ukrainian literary language: The structure of the scientific text]. Kyiv: Vyd-vo Kyiv. un-tu [in Ukrainian]. 2. Morshchakova, T. V. (1992) Semanticheskie xarakteristiki terminov ugolovnogo zakona (na materiale russkogo, nemeckogo, anglijskogo yazykov) [Semantic characteristics of the terms of the criminal law (on the material of Russian, German, English)] Candidate's thesis. Moscow: Voen. krasnoznam. in-t [in Russian]. 3. Novostavska, O. (2013) Paradyhmatychni vidnoshennia (synonimiia ta antonimiia) u filosofskii terminolohii tvoriv Ivana Franka [Paradigmatic relations (synonymy and antonymy) in the philosophical terminology of Ivan Franko's works]. Ukrainian language - Ukrainska mova, 2, 68-75 [in Ukrainian]. 4. Petrova, T. O. (2018) Fitomelioratyvna terminolohiia suchasnoi ukrainskoi movy ta yii vidobrazhennia $v$ terminolohichnomu slovnyku kombinovanoho typu [Phytomeliorative terminology of modern Ukrainian language and its reflection in the terminological dictionary of combined type]. Kharkiv: TOV «TPH» [in Ukrainian]. 5. Pyvovarov, V. M., Yerakhtorina, O. M., \& Lysenko, O. A. et al. (2020) Mova ukrainskoi yurysprudentsii [The language of Ukrainian jurisprudence]. Kharkiv: Pravo [in Ukrainian]. 6. Piletsky, V. Some linguistic problems of Ukrainian terminology. 
Ukrainian spelling and scientific terminology: problems of norm and modernity [Some linguistic problems of Ukrainian terminology. Ukrainian spelling and scientific terminology: problems of norm and modernity]. Materialy zasidan Movoznavchoi komisii i Komisii vsesvitnoi literatury NTSh u Lvovi 1996-1997 rr. - Meetings of the Linguistic Commission and the Commission of World Literature of the NTSh in Lviv in 1996-1997 (pp. 115-118). Lviv: Nauk. tov. im. Shevchenka u Lvovi [in Ukrainian]. 7. Pravozakhysnyk vs pravookhoronets? [Human rights activist vs law enforcement?]. "ZN, UA», 2, 24.01.2014. Retrieved from https://zn.ua/ukr/SOCIUM/pravozahisnik-vs-pravoohoronec-.html [in Ukrainian]. 8. Rusanivskyi V. M., Taranenko O. O., \& Ziabliuk M. P. (Eds.). (2004). Ukrainska mova. Entsyklopediia [Ukrainian language. Encyclopedia]. Kyiv: Ukr. entsykl. im. M. P. Bazhana [in Ukrainian].

Удовіченко Лілія Геннадіївна - аспірант кафедри української мови, Харківський національний педагогічний університет імені Г. С. Сковороди; вул. Валентинівська, 2, м. Харків, 61168, Україна.

Tel.: +38-095-160-89-46

E-mail: vorotnikova225@gmail.com

https://orcid.org/0000-0001-5953-2923

Udovichenko Liliia Hennadiivna - Postgraduate Student at the Department of Ukrainian Language, H. S. Skovoroda Kharkiv National Pedagogical University; 2 Valentynivska Str., Kharkiv, 61168, Ukraine.

Надійшла до редакції 5 березня 2021 року

\section{CITATION}

ДСТУ 8302:2015: Удовіченко Л. Г. Парадигматичні відношення в сучасній українській правоохоронній термінології. Лінгвістичні дослідження: зб. наук. пр. Харк. нац. пед. ун-ту імені Г. С. Сковороди. Харків, 2021. Вип. 54. Ч. II. С. 23-31. DOI: https://doi.org/10.34142/23127546.2021.54.2.03

AРA: Удовіченко, Л. Г. (2021). Парадигматичні відношення в сучасній українській правоохоронній термінології. Лінгвістичні дослідження, 54 (II), 23-31. DOI: https://doi.org/10.34142/23127546.2021.54.2.03 